\title{
Historia cięcia tlenem
}

\section{The history of oxygene cutting}

\begin{abstract}
Streszczenie
W artykule przedstawiono historię cięcia wodorowo - tlenowego i acetylenowo - tlenowego. Opisano sposób pozyskiwania tlenu oraz gazów palnych do cięcia. Przedstawiono również pierwsze palniki, $w$ tym palniki do cięcia pod wodą, a także metody mechanizacji procesu i pierwsze maszyny do cięcia.
\end{abstract}

Słowa kluczowe: palnik, cięcie pod wodą

\section{Abstract}

The paper presents the history of hydrogen-oxygen and acetylene-oxygen cutting. The metod of obtaining the oxygen and fuel gases was described. The first blowpipes, including the underwater cutting blowpipes and the methods of mechanization of process and the first thermal cutting machines was also presented.

Keywords: blowpipe, torch, underwater cutting

\section{Wstęp}

Cięcie gazowe zaczęto stosować na przełomie XIX i XX wieku, jednak podstawowe prawo cięcia przedstawił Francuz Antoine Lavoisier, który w 1776 r, przeprowadził doświadczenie polegające na spalaniu żelaznej spirali w słoju wypełnionym tlenem. Stwierdził on, że tworzący się tlenek jest łatwiej topliwy niż sam metal i odpada w miarę powstawania. Sześćdziesiąt lat później H. Sainte-ClaireDeville zauważył, że jeśli prowadzi się nagrzewanie, przy zwiększonym udziale tlenu, to stal pali się, a nie topi [1].

Dzięki odkryciom fizyków i chemików możliwe więc było opracowanie nowych technologii łączenia i cięcia metali.

Cięcie tlenowe, obejmujące cięcie wodorowo-tlenowe i acetylenowo-tlenowe mogło się rozwinąć gdy rozwinęła się znacząca produkcja gazów palnych i silnego utleniaczaczystego tlenu.

\section{Gazy w procesie cięcia}

Pierwszym stosowanym gazem opałowym był wodór. Gaz ten był już znany alchemikom średniowiecznym, jednak jego właściwości zostały opisane dopiero w XVIII w. przez angielskiego badacza H. Cavendisha [1].

Po raz pierwszy zastosowano wodór jako gaz spawalniczy w 1896 r. w Niemczech. Inżynier E. Wiss, zatrudniony w Chemische Fabrik Griesheim, do naprawy zbiorników i rur ołowianych użył palnika wodorowo-powietrznego skonstruowanego w 1841 r. przez Francuza E. Des Bassayns de Richemont`a. Wodór potrzebny do zasilania palnika uzyskano w wyniku reakcji cynku z rozcieńczonym kwasem siarkowym. Było to rozwiązanie jednorazowe, gdyż w zakładzie tym wodór był produktem ubocznym, uzyskiwanym w produkcji chloru metodą elektrolizy zasadowych chlorków i zaczęto go gromadzić w stalowych cylindrach [1].

W latach późniejszych wodór wytwarzano wyłącznie przez elektrolizę wody [2].

Kolejnym gazem palnym stosowanym w procesach cięcia był acetylen. Pierwszy własności acetylenu podał w 1836 r. Edmund Davy, jednak błędnie określił jego wzór $\mathrm{C}_{2} \mathrm{H}$ i nazwał go dwuwęglikiem wodoru. Dokładny wzór $\mathrm{C}_{2} \mathrm{H}_{2}$ podał w $1860 \mathrm{r}$. francuski chemik Marcelin Berthelot. Określił on reakcję, w której tworzy się ten gaz i nadał mu aktualną nazwę - acetylen [1].

Acetylen uzyskiwano z karbidu, który został odkryty w 1862 r. przez Fryderyka Wöhlera [3]. Wöhler uzyskał karbid przez działanie rozżarzonego węgla na cynk i wapń, jednak proces wytwarzania karbidu opatentował Kanadyjczyk Thomas Willson w 1893 r. Uzyskał on karbid podczas produkcji metalicznego wapnia przez redukcję wapna węglem w piecu łukowym [1]. Przemysłową metodę otrzymywania karbidu podał w 1894 r. Henryk Maisson [7].

Acetylen z karbidu produkowano trzema metodami: do zbiornika z wodą wrzucano w pewnych odstępach czasu karbid, do zbiornika z karbidem wpuszczano kroplami wodę lub zbiornik z karbidem zalewano wodą, która pod ciśnieniem powstałego gazu była wypierana do naczynia otaczającego zbiornik i przy zmniejszeniu ciśnienia ponownie dopływała do karbidu [2]. W praktyce najczęściej stosowano pierwszą metodę. Uzyskany acetylen próbowano magazynować $w$ butlach stalowych, jednak było to utrudnione, gdyż jak stwierdził Berthelot acetylen przy podwyższaniu ciśnienia rozkłada się w sposób wybuchowy. Problem ten rozwiązało dwóch francuskich inżynierów G. Claude i A. Hess, którzy zauważyli, że aceton rozpuszcza znaczne ilości acetylenu, przy czym rozpuszczalność acetylenu rośnie wraz z ciśnieniem. Zasługa technicznego zastosowania acetonu przypadła jednak Gustawowi Dalenowi,

Dr inż. Anna Pocica - Politechnika Opolska. 
który w 1905 r. opracował masę porowatą wypełniającą butlę. Masę tę nazwał "Aga-masą" i składała się ona z cementu krzemianowego, specjalnego węgla drzewnego, spoiwa i włókien azbestu [4]. Dzięki temu odkryciu możliwe było przechowywanie acetylenu w butlach przy ciśnieniu do 1,5 MPa.

Do spalania gazów palnych niezbędny był tlen. Gaz ten został wyodrębniony w drugiej połowie XVIII w. przez J. Priestley`a w Anglii, K. Scheele w Szwecji i Francuza A. Lavoisier`a [5]. W 1851 r. francuski chemik Baussignault otrzymał tlen z powietrza, podgrzewając w powietrzu tlenek baru, w wyniku czego powstawał nadtlenek baru, który przy dalszym ogrzewaniu uwalniał tlen. W tym samym czasie i w tym samym celu Niemiec Kassner stosował ołowian wapnia, jednak ze względu na znaczne koszty proces ten nie został nigdy wdrożony [1].

Kolejną metodą uzyskiwania tlenu była elektroliza wody przeprowadzona około 1888 r. przez Renarda, Latchionova i Schuckerta i udoskonalona przez P. Garrutiego w 1892 r.

Największe znaczenie techniczne miała metoda skroplenia powietrza. Do połowy XIX w. uważano, że powietrze jest gazem trwałym, nie dającym się skroplić. Bezskuteczne próby skroplenia powietrza, przy użyciu ciśnienia dochodzącego do 36,5 MPa, prowadzili Perkins, Faraday, Netler, Aime i Berthelot. Dopiero L. Cailletet i R. Pictet w 1877 r. skroplili niewielką ilość tlenu i azotu, sprężając gaz w obniżonej temperaturze i następnie gwałtownie go rozprężając [6]. W 1883 r. K. Olszewski i Z. Wróblewski, stosując udoskonaloną aparaturę Cailleteta skroplili powietrze, uzyskując tlen i azot [1].

Na skalę techniczną skroplenia powietrza dokonał w $1895 \mathrm{r}$. C. Linde. W metodzie Lindego gaz oziębiał się i skraplał wyłącznie przez rozprężanie się (rys. 1). Pierwsza instalacja Lindego produkowała 3 litry ciekłego powietrza na godzinę [8]. W 1902 r. Linde zbudował aparaturę umożliwiającą produkcję tlenu przez skroplenie powietrza [1].

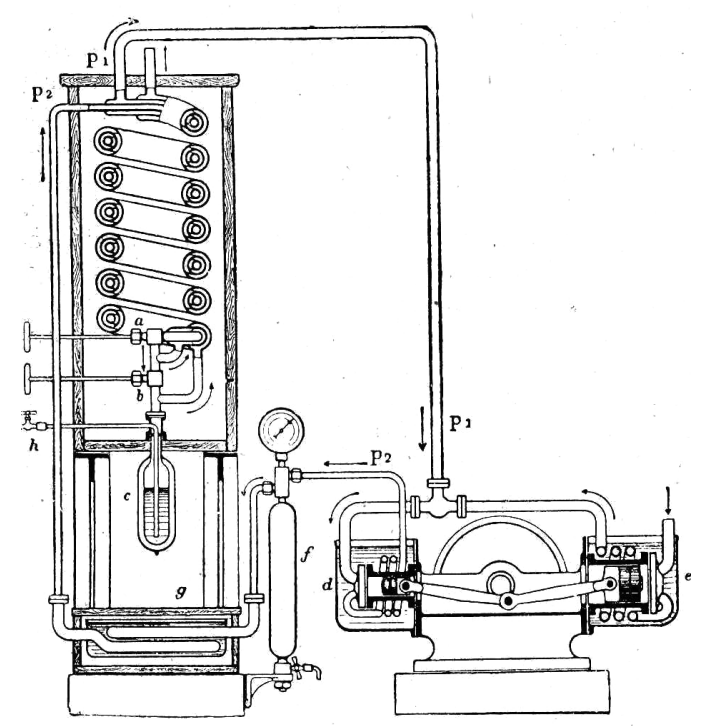

Rys. 1. Sprężarka do skraplania powietrza Linde`go [6]

Fig. 1. Linde's compressor for gas liquefying

\section{Palniki do cięcia tlenowego}

Pierwsze palniki gazowe były przeznaczone do topienia metalu a także do spawania.

W latach trzydziestych XIX w. Francuz H. Sainte-ClaireDebille skonstruowat palnik wodorowy do topienia platyny i produkcji emalii [1]. Kolejny palnik wodorowy, wynaleziony przez E. Debassayn de Richmont`a, został wykorzystany do spawania ołowiu. Wodór wytwarzano w miejscu użytkowania, a powietrze do palnika podawano pod niewielkim nadciśnieniem. Inny palnik wodorowy skonstruował w 1897 r. inż. E. Wiss. W palniku tym gaz palny (wodór) służył do zasysania gazu utleniającego (powietrza).

Pierwsze informacje o wykorzystaniu palników wodorowych do cięcia przedstawił T. Fletcher w 1890 r. na konferencji w Oxfordzie. Twierdził on, że skonstruowanym przez niego w 1888 r. palnikiem (rys. 2) można ciąć blachy o grubości $6 \mathrm{~mm}$ z szybkością $75 \mathrm{~mm} / \mathrm{min}$ [1]. Proces cięcia zaproponowany przez Fletchera opierał się jednak na topieniu, a nie spalaniu metalu.

Podobny błąd popełnił belgijski inżynier F. Jottrand. Palnik jego konstrukcji (rys. 3) powodował również topienie metalu i dlatego w 1904 r. wraz z inż. Lulli skonstruował palnik wodorowo-tlenowy z dodatkową rurą zasilającą czystym tlenem [9]. Inny palnik do cięcia wodorowo-tlenowego skonstruował w 1903 r. Ernst Wiss (rys. 4).

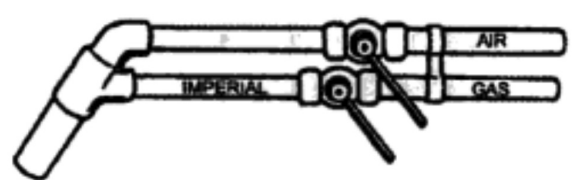

Rys. 2. Palnik konstrukcji T. Fletchera z 1888 r. [9] Fig. 2. Blowpipe of T. Fletcher's construction from 1888

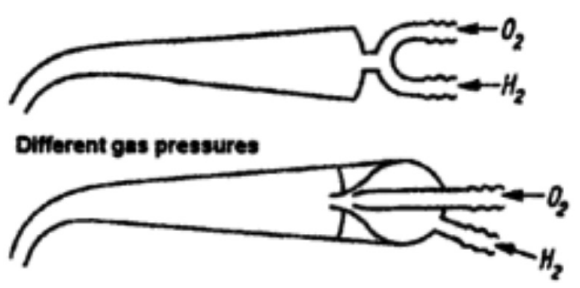

Rys. 3. Palnik F. Jottranda [9]

Fig. 3. F. Jottrand's blowpipe

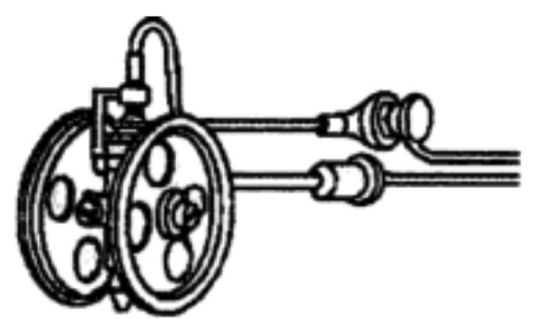

Rys. 4. Palnik E. Wissa [9]

Fig. 4. E. Wiss's plowpipe

a)

b)

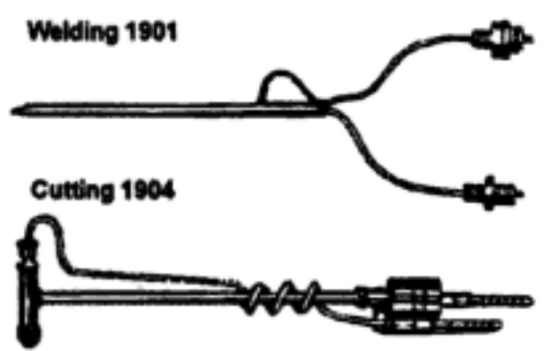

Rys. 5. Palniki Picarda i Fouche [9]

Fig. 5. Picard's and Fouche's blowpipes

Pierwszy palnik wykorzystujący acetylen jako gaz palny (rys. 5a) zbudowali w 1901 r. C. Picard i E. Fouche. Trzy lata później przystosowali ten palnik do cięcia (rys. 5b) [1,9].

Palniki do cięcia były skonstruowane podobnie jak palniki do spawania, z tą różnicą, że posiadały dodatkową dyszę, zwaną gilzą, dla strumienia czystego tlenu [10]. Dysza dla mieszanki acetylenu z tlenem i gilza dla czystego 
tlenu były umieszczone obok siebie (rys. 6) lub też gilza była osadzona współśrodkowo z dyszą (rys. 7) [11]. Pierwsze rozwiązanie pozwalało na uzyskanie głębszego i węższego przecięcia, drugie na przecinanie elementów o znacznej grubości oraz cięcie po łuku lub pod kątem [12].

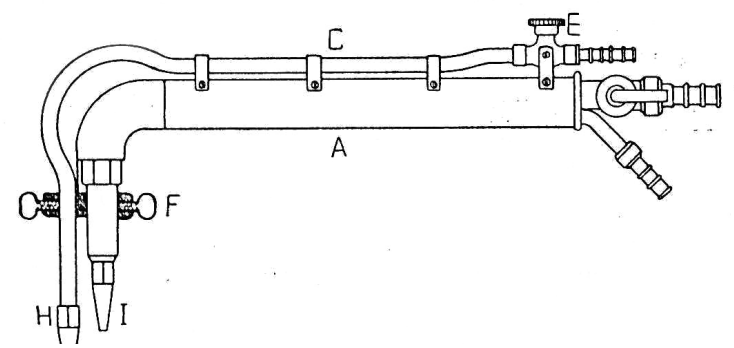

Rys. 6. Palnik do cięcia z dodatkową dyszą tlenową [14], A - palnik do spawania, C - przewód do tlenu, E - regulacja dopływu tlenu, $\mathrm{H}$ - dysza doprowadzająca tlen, $\mathrm{F}$ - regulacja wysokości dyszy tlenu, I - dysza palnika

Fig. 6. Burner for cutting with additional oxygen nozzle. A - Torch for welding, $\mathrm{C}$ - pipe for oxygen, E - oxygen inflow adjustment, $\mathrm{H}$ - nozzle of oxygen inflow, $\mathrm{F}$ - adjustment of oxygen nozzle position, I - nozzle of burner

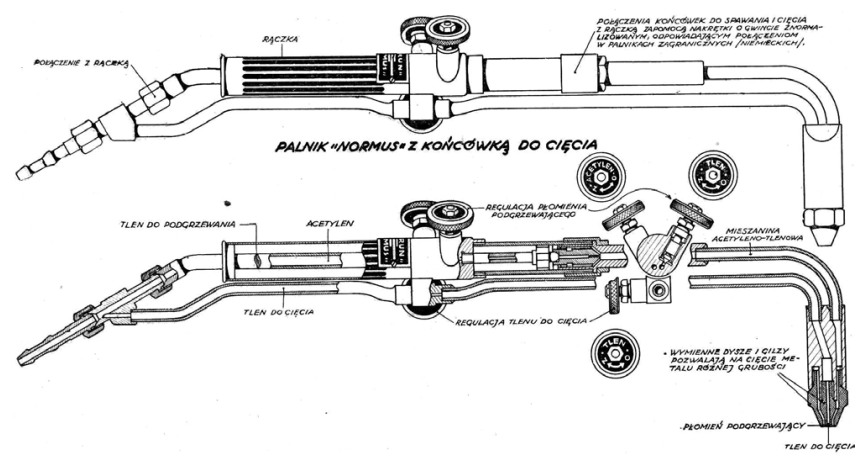

Rys. 7. Palnik uniwersalny z założoną końcówką do cięcia [11] Fig. 7. All-purpose blowpipe with tip for cutting

Do 1919 r. w Polsce nie produkowano palników do spawania i cięcia, manometrów redukcyjnych itp. [13]. Pierwszą firmą w kraju , która rozpoczęła produkcję sprzętu do spawania i cięcia było Towarzystwo Akcyjne Perun i już po paru latach produkowano 12 typów palników, w tym 3 przeznaczone do cięcia i 3 uniwersalne do spawania i cięcia [15].

Odmienną budowę miały palniki do cięcia pod wodą, co wynikało ze specyficznych warunków ich pracy.

Pierwszy patent na cięcie pod wodą uzyskano w Niemczech w 1909 r. [1]. Kolejny patent Andressa z 1912 r. nigdy nie został zrealizowany [16].

W 1913 r. w Towarzystwie Acetylene Dissons et Applications de l'Acetylene skonstruowano aparat do cięcia pod wodą. Płomień gazowy palił się w kloszu o szerokim wylocie, do którego doprowadzano sprężone powietrze (rys. 8). Strumień sprężonego powietrza odchylał palnik od przecinanego przedmiotu, a unoszące się ku górze powietrze mąciło wodę, co ograniczało widoczność i utrudniało ciecie. Ponadto płomień często gasł w trakcie pracy, co wymagało powrotu na powierzchnię celem ponownego zapalenia palnika [16].

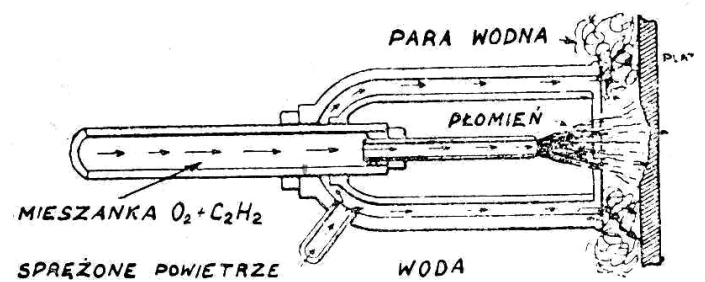

Rys. 8. Schemat pierwowzoru palnika do cięcia pod wodą z doprowadzeniem sprężonego powietrza [16]

Fig. 8. Scheme of blowpipe prototype for underwater cutting with compressed air supply
Palnik, w którym wyeliminowano osłonę płomienia sprężonym powietrzem skonstruował Picard w 1923 r. W palniku tym zastosowano na dyszy palnika małą komorę otaczającą jądro płomienia (rys. 9). Komora pozwoliła na utrzymanie wokół płomienia atmosfery wytworzonej przez gazy palne, co zapobiegało jego gaśnięciu. Palnik ten został również wyposażony w specjalne urządzenie do zapalania. Była to komora, do której dopływał strumień tlenu, a w środku był umieszczony dopływ acetylenu, w ten sposób, że większa część płomienia paliła się we wnętrzu komory i tylko koniec płomienia wychodził poza otwór. Chcąc zapalić palnik wystarczyło zbliżyć płomień zapalnika do dyszy, otworzyć dopływ tlenu do podgrzewania, a następnie dopływ acetylenu [16].

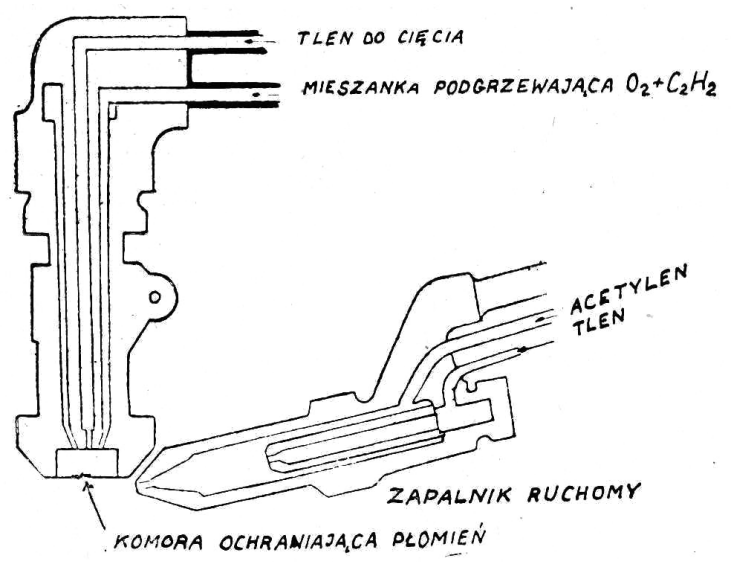

Rys. 9. Schemat końcówki palnika acetylenowo-tlenowego do cięcia pod wodą [16]

Fig. 9. Scheme of acetylene-oxygen blowpipe tip for underwater cutting

Cięcie pod wodą stosowano do wydobywania i rozbierania statków, przecinania zagród wodnych oraz do napraw przewodów kanalizacyjnych znajdujących się pod wodą. Jedynym ograniczeniem procesu była głębokość , na której wykonywano pracę. Przy pracach na większych głębokościach należało zwiększyć ciśnienie acetylenu by zrównoważyć ciśnienie słupa wody. Nadmierny wzrost ciśnienia mógł jednak prowadzić do rozkładu i eksplozji acetylenu, w związku z czym maksymalna głębokość pracy byłą ograniczona do $12 \mathrm{~m}$ [16].

Do cięcia gazowego oprócz palników stosowano również lance tlenowe. Idea lancy tlenowej po raz pierwszy została przedstawiona przez Anglika Thomasa Fletchera w 1882 r. podczas obrad Towarzystwa Przemysłu Chemicznego, natomiast pierwszy patent uzyskał Ernst Henner w Niemczech w 1901 r.

Lanca tlenowa byłą zbudowana z dwóch koncentrycznych rur. W rurze centralnej płynął strumień tlenu pod niskim ciśnieniem, a w przestrzeni między wewnętrzną i zewnętrzną rurą płynął gaz palny. Mieszanka gazów spalała się na końcu lancy, który był skierowany na cięty materiał. Gdy materiał został nagrzany do temperatury białego żaru zwiększano ciśnienie tlenu, w wyniku czego następowało wypalanie szczeliny w materiale [1]

\section{Cięcie maszynowe}

Dążenie do zmniejszenia kosztów produkcji, poprawy jakości i skrócenia czasu cięcia spowodowało podjęcie prób mechanizacji procesu.

Proste rozwiązania, pozwalające wyeliminować drgania nieuniknione przy cięciu ręcznym, zaproponował inż. Eberle [17]. Skonstruował on aparat (rys. 10), do którego mocowano 
palnik wprawiany w ruch z pomocą kółka z korbką. Równomierny ruch palnika osiągnięty dzięki takiemu rozwiązaniu pozwalał zwiększyć dokładność, a także szybkość cięcia.

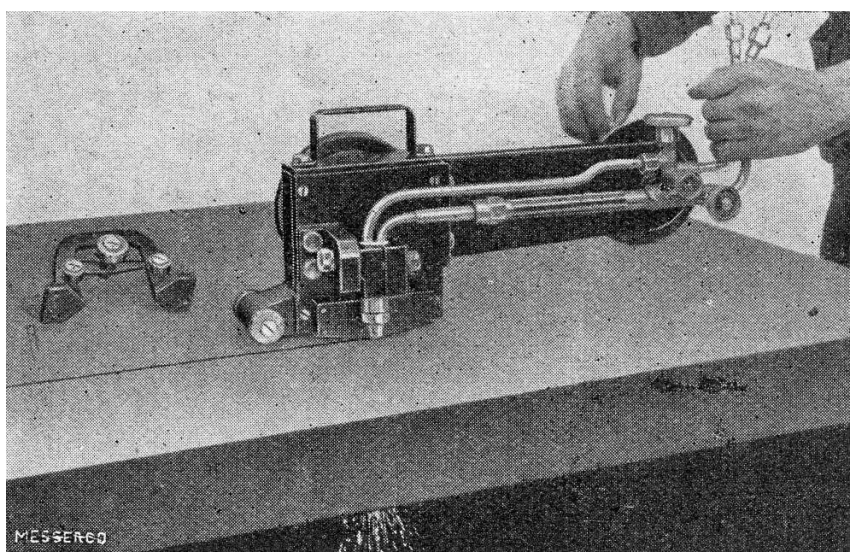

Rys. 10. Aparat do cięcia z zamocowanym na nim palnikiem [17] Fig. 10. Device for cutting with attached blowpipe

Kolejne rozwiązanie warsztatowe do cięcia prostoliniowego przedstawiono na rysunku 11. Przedstawione urządzenie było wykonane z ceowników. Dwa górne ceowniki z przyspawaną płaską blachą na obu końcach tworzyły prowadnicę dla suportu osadzanego na zwykłej śrubie pociągowej ze starej tokarki, Prowadnica była połączona z dolnym ceownikiem za pomocą sprężyn, które dociskały ciętą blachę opartą na dolnym ceowniku $[18,19]$.

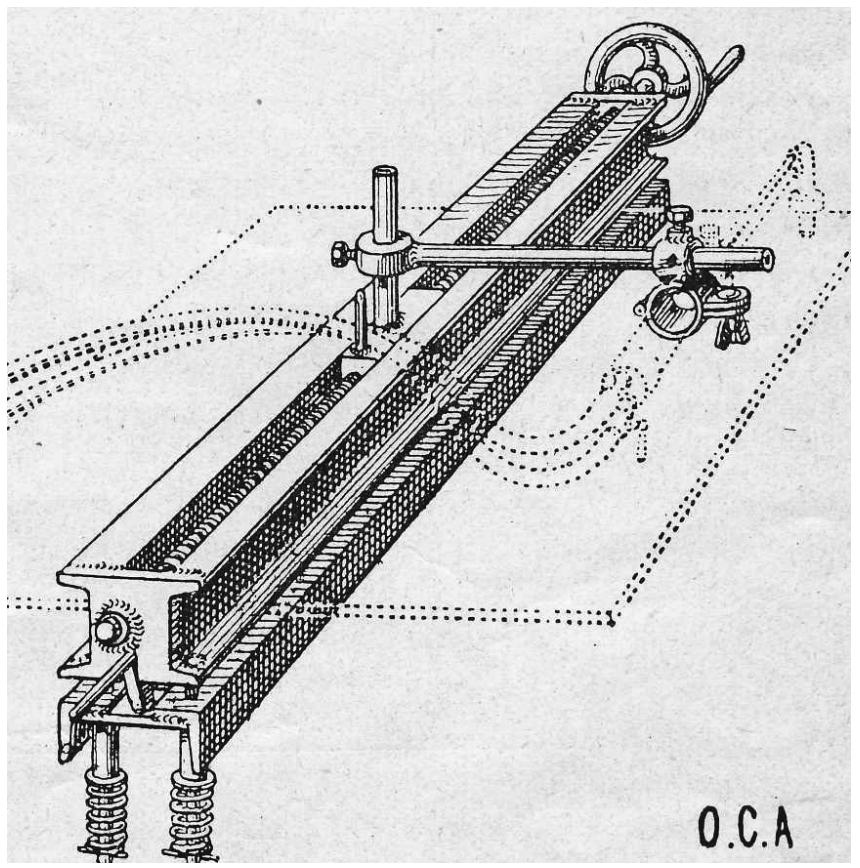

Rys. 11. Aparat do cięcia z zamocowanym na nim palnikiem [17] Fig. 11. Device for cutting with attached blowpipe

W przypadku cięcia rur, wałków lub prętów o średnicy 20-300 mm można było zastosować proste rozwiązanie o nazwie "Kitourn” [19]. Przyrząd ten (rys. 12) składał się z dwóch par nóżek połączonych równolegle ze sobą i tworzących kąt, którego rozwarcie można było regulować. Palnik zakładany do uchwytu ustawiano tak, by płomień był skierowany prostopadle do przecinanego przedmiotu. Po rozpoczęciu cięcia, za pomocą rączki, obracano przyrząd wraz z palnikiem dookoła nieruchomego przedmiotu.

Z kolei urządzenie „Kiroul” (rys. 13) można było stosować do wycinania otworów o średnicy 10-30 mm w blachach, kształtownikach, szynach itp. W urządzeniu tym na podstawie była zamontowana okrągła prowadnica. Palnik do cięcia spoczywał w uchwycie na podstawie, a dysza opierała się na okrągłej podstawce, która jednocześnie była szablonem. Celem uruchomienia aparatu na dyszę kładziono szablon (koło c na rys. 1 4) o średnicy wycinanego otworu. Prowadząc kółko po wewnętrznej średnicy szablonu otrzymywano wycięcie o żądanej średnicy (linia kreskowa na rys. 14). Im średnica wycinanego otworu była mniejsza tym kółko większe [19].

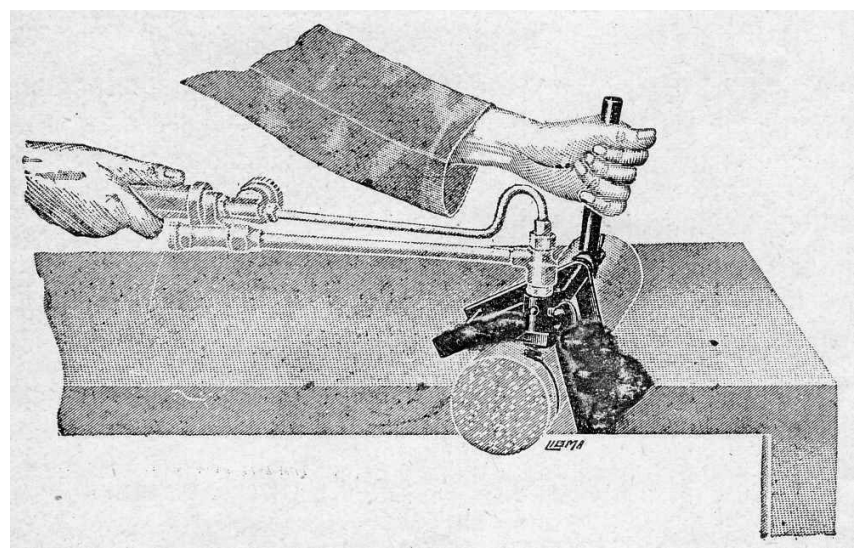

Rys. 12. Przecinanie wałka za pomocą prowadnicy „Kitourn” [19] Fig. 12. Cutting of roller with "Kitourn" cutting guide

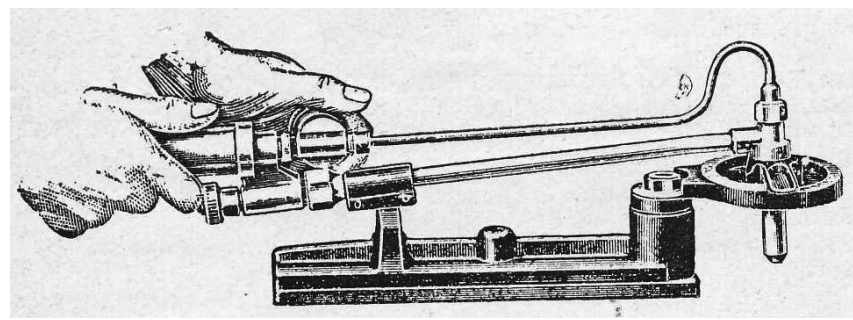

Rys. 13. Prowadnica "Kiroul do wycinania otworów o średnicy 10-30 mm [19]

Fig. 13. Kiroul" cutting guide for $10-30 \mathrm{~mm}$ diameter holes

Duże warsztaty i zakłady potrzebowały profesjonalnych maszyn, umożliwiających cięcie po linii prostej, często przedmiotów o znacznych przekrojach (300-400 mm), wycinanie skomplikowanych kształtów lub też maszyn zapewniających wszystkie możliwe warianty cięcia [20]. Maszyny do cięcia można było kupić za granicą lub stosować maszyny produkowane w Pol-

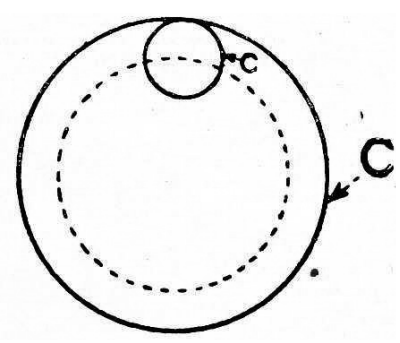

Rys. 14. Schemat prowadzenia palnika

Fig. 14. Scheme of torch guiding sce przez Spółkę Akcyjną Perun.

W 1911 r. Zakłady Davis Bournonville w Nowym Jorku wypuściły na rynek pierwszą maszynę do cięcia o nazwie "Oxygraph", działającą na zasadzie pantografu. W procesie cięcia na stole mocowano odpowiedni szablon, po którego konturze prowadzono kółko pantografu. Ruch pantografu był odtwarzany przez palnik, co umożliwiało wycinanie różnych kształtów (rys. 15) [21,26].

Konstrukcja "Oxygraphu” była bardzo prosta. Na stole roboczym zamontowana była oś (lewa strona rys. 15), wokół której obracało się ramię pantografu. Z drugiej strony stołu roboczego umieszczony był stolik służący do umieszczenia rysunku. Ramię pantografu było zakończone kółkiem, które prowadzono po konturze rysunku. Kółko to było wprowadzane 
w ruch za pomocą małego silniczka, umieszczonego na końcu ramienia, a także mogło się obracać wraz z oprawą wokół osi pionowej. Ruch obrotowy kółka pozwalał na utrzymanie jednostajnej, ściśle określonej szybkości pracy, a także ułatwiał robotnikowi obrysowanie konturu. „Oxygraph” pozwalał na przecinanie stali o grubości 75 mm z szybkością 150 $\mathrm{mm} / \mathrm{min}[21]$.

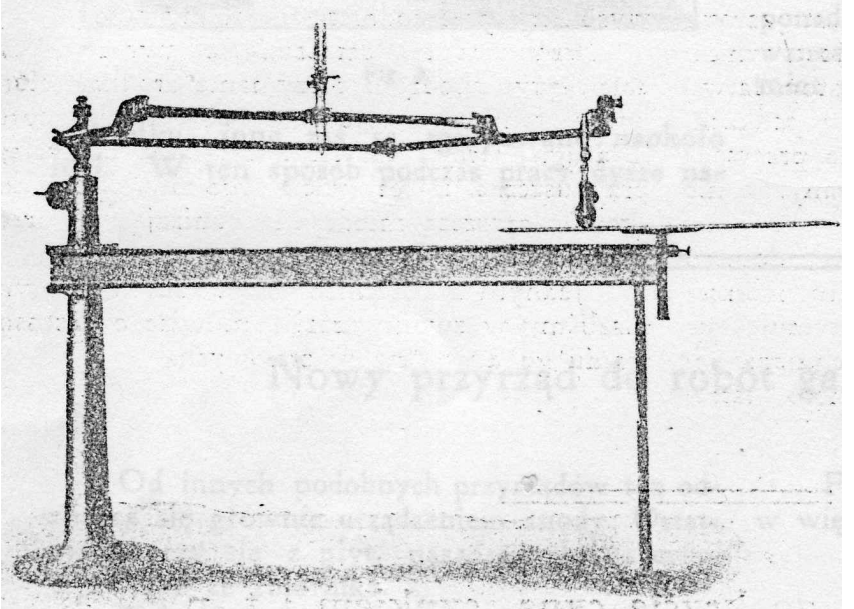

Rys. 15. Pierwsza maszyna do cięcia "Oxygraph" [21]

Fig. 15. "Oxygraph" - the first device for cutting

Inna była zasada działania maszyny A. Godfrey’a (rys. 16), skonstruowanej w 1919 r. Była to maszyna uniwersalna, pozwalająca na wycinanie dowolnych kształtów, otworów o średnicy od 40 do $900 \mathrm{~mm}$. Dzięki zastosowaniu obrotowego stołu, którego obciążenie mogło dochodzić do 8 ton, można było wycinać koła o średnicy do $5 \mathrm{~m}$. Każda maszyna była wyposażona w specjalne urządzenie do ciecia dużych sześciu i ośmiokątnych nakrętek, krzywek, kołnierzy itp. Zastosowany do ciecia palnik na wysokie ciśnienie zapewniał uzyskanie gładkiej powierzchni cięcia, o nierówności nie przekraczającej 0,2 mm [22].

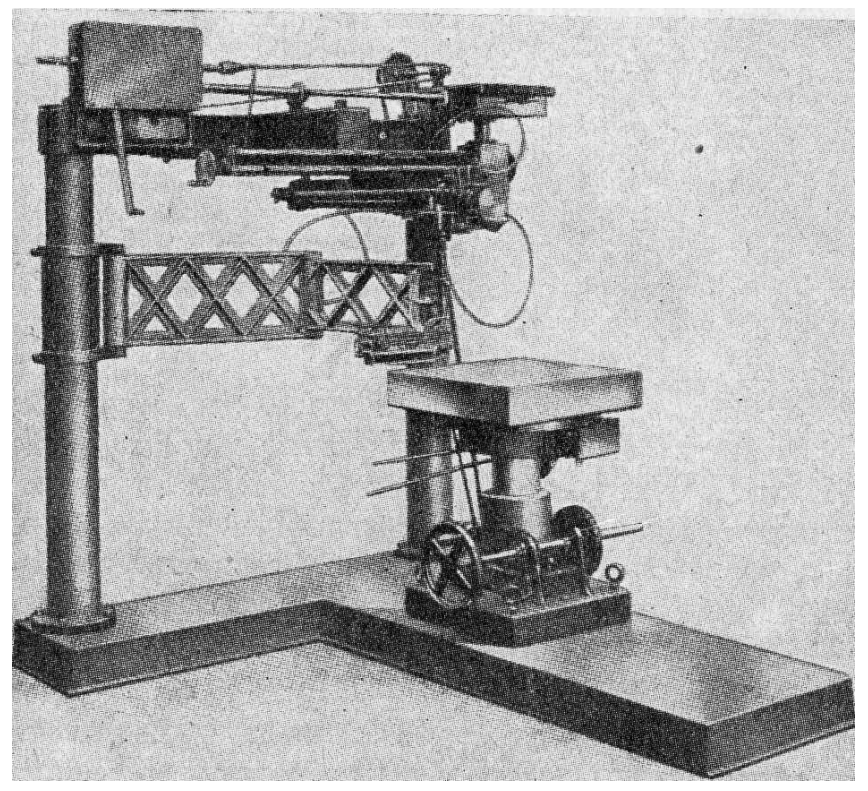

Rys. 16. Maszyna Godfrey`a do cięcia [22]

Fig. 16. Godfrey's device for cutting

Z europejskich konstrukcji warto przedstawić maszynę zbudowaną w latach dwudziestych XX w. w firmie Messer (rys. 17). Urządzenie to umożliwiało cięcie proste pod dowolnym kątem, cięcie skomplikowanych kształtów i cięcie o dowolnym łuku przy zastosowaniu szablonów. Szablony składały się z cienkiej mosiężnej lub aluminiowej taśmy, którą przymocowywano niewielkim gwoździami do odpowiednich szablonów drewnianych. Szybkość cięcia oraz ciśnienie gazów nastawiano wg specjalnej tabeli dołączanej do maszyny, dzięki czemu mógł ją obsługiwać spawacz o niewielkim doświadczeniu [23].

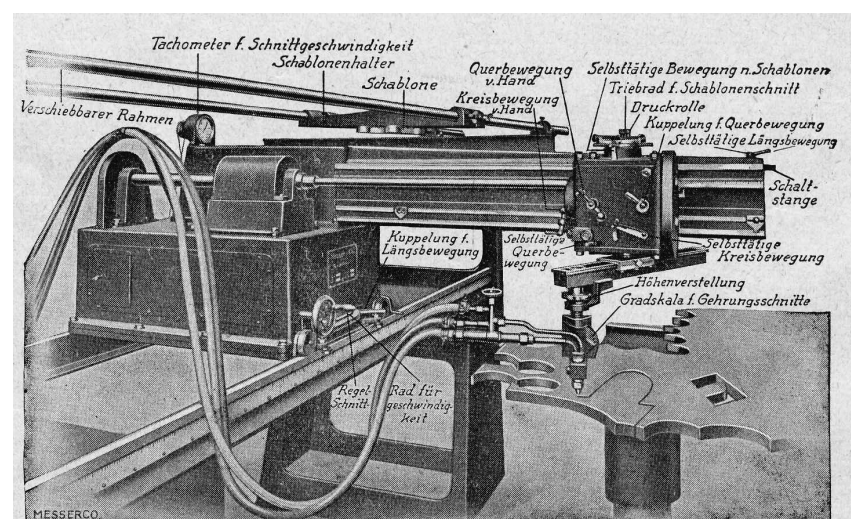

Rys. 17. Maszyna do cięcia firmy Messer [23]

Fig. 17. Device for cutting by Messer Company

W Polsce maszyny do cięcia produkowała Sp. Akc. Perun. Głównie były to maszyny uniwersalne typu Oxytom (rys. 18), maszyna Pantonom B33 (rys. 19), maszyna Pyrotom z prowadzeniem ręcznym (rys. 24) i Serwotom (rys. 25) z prowadzeniem automatycznym, a także dwie maszyny do cięcia bloków (rys. 26 i 27) [15,24,25,27,28]

Maszyny typu Oxytom (rys. 18) były to maszyny o stałej podstawie. Przesuw odbywał się po szynach zamocowanych na stole, a nie bezpośrednio po ciętym elemencie. Palnik przemieszczał się w kierunku ruchu wypadkowego, składającego się z ruchu podłużnego maszyny po szynach i poprzecznego, który wykonywało ramię wraz z palnikiem.

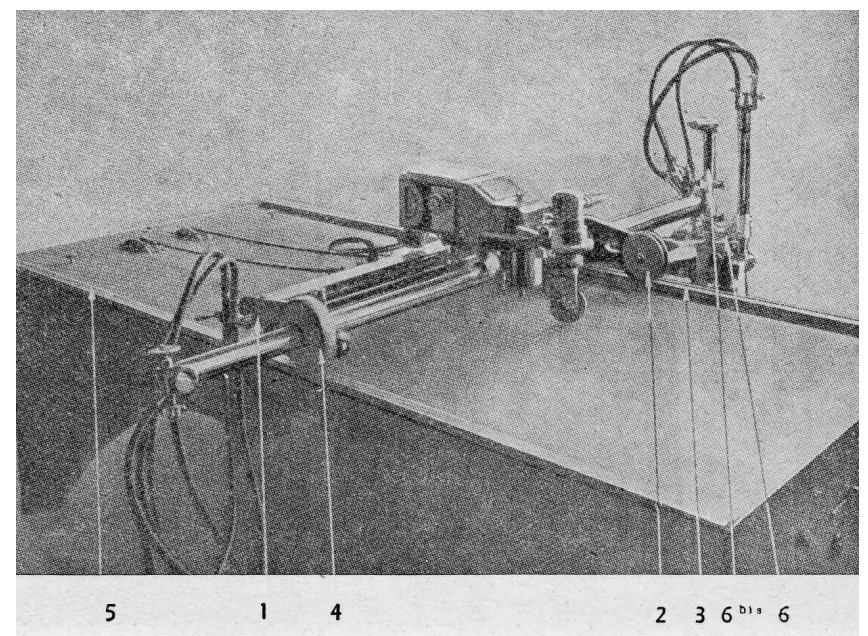

Rys. 18. Maszyna Oxytom produkowana przez Sp. Akc. Perun [15] Fig. 18. Oxytom device produced by Perun Sp. Akc.

Korpus maszyny składał się z wózka wyposażonego w trzy krążki, z których dwa (2) przemieszczały się po prowadnicy (3), a trzeci (4) po płaskowniku (5). Przez krążek (4) przechodziła rura, na której z jednej strony był zamontowany suport palnika, a po środku mechanizm poruszający maszynę. Palnik był wsparty na wsporniku (6) połączonym z kolumienką (6bis) Ruch palnika w kierunku pionowym uzyskiwano przy pomocy kółka zębatego i drążka [15].

Maszyny Oxytom produkowano w dwóch wersjach; Oxytom I przeznaczony był do warsztatów średniej wielkości wykonujących bieżące roboty ślusarskie, kotlarskie itp. oraz Oxytom II umożliwiający wykonywanie poważniejszych robót seryjnych, np. cięcie większej ilości materiałów o znacznej grubości [24]. Obie maszyny miały taką samą 
zasadę działania, różnica dotyczyła tylko prowadzenia palnika i sposobu zmiany szybkości posuwu. W Oxytomie I prowadzenie palnika realizowano za pomocą szablonu wykonanego z paska miedzi, po krawędzi którego przesuwał się krążek prowadzący z poziomą ośką. Szybkość $w$ tym rozwiązaniu zmieniano skokowo zmieniając ręcznie przekładnie. W maszynie Oxytom II prowadzenie palnika realizowano przez przeciąganie magnetyczne krążka prowadzącego przesuwającego się po krawędzi stalowego szablonu. Zmiana szybkości była płynna, przez regulację za pomocą gałki obrotowej [15].

Maszyna Pantotom B33 (rys. 19), była udoskonaloną wersją maszyny Pantotom B (rys. 20) i wyróżniała się tym, że przy niskiej cenie miała bardzo szerokie zastosowanie, dzięki nieograniczonemu posuwowi wzdłużnemu. Była to maszyna o prostej konstrukcji, małym ciężarze - ok. 80 kg, zajmowała mało miejsca i nie wymagała fundamentów. Pantotom 33B był maszyną uniwersalną do wycinania dowolnych kształtów z blach o grubości 3-600 mm. Zazwyczaj maszyna przemieszczała się po stole pokrytym blachą, ale w sytuacjach nadzwyczajnych, ze względu na mały ciężar, mogła się też przemieszczać po przecinanej blasze.

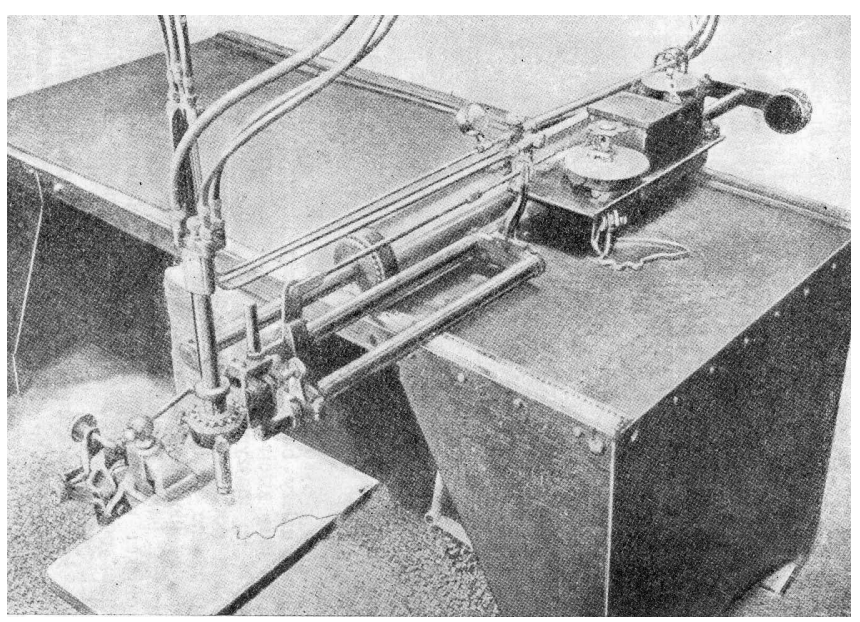

Rys. 19. Maszyna Pantotom B33 [27]

Fig. 19. Pantotom $B 33$ device

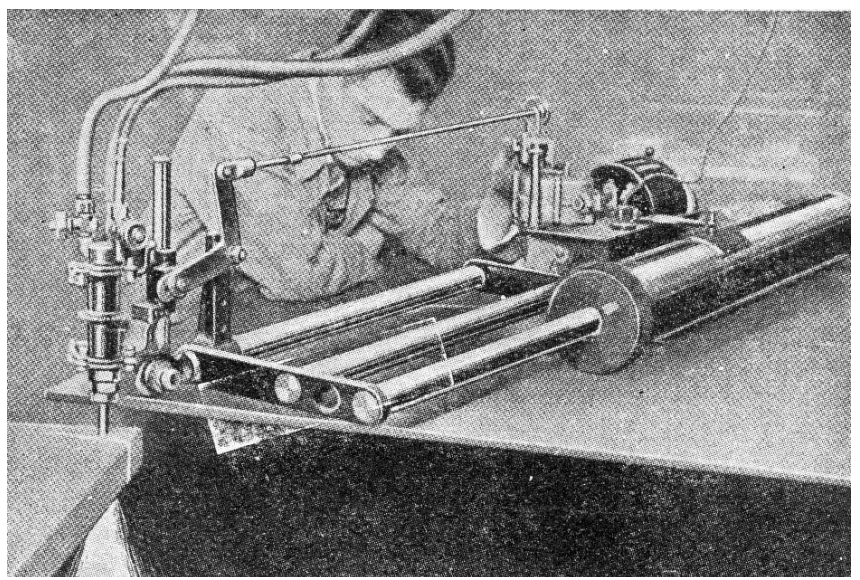

Rys. 20. Maszyna Pantotom B [27]

Fig. 20. Pantotom $B$ device

Dodatkowo maszyna była wyposażona w specjalny cyrkiel (rys. 21 a) do wycinania tarcz i kryz o średnicy 50-750 mm, przyrząd do ukosowania w dowolnych kierunkach (rys. 21b) oraz specjalny przyrząd do wycinania kół o średnicy większej niż 750 mm (rys. 21c) [27].

Maszyna Pyrotom (rys. 22) była to maszyna o napędzie elektrycznym, z prowadzeniem ręcznym i automatycznym posuwem przeznaczona do cięcia elementów o grubości do $300 \mathrm{~mm}$. Również urządzenie Serwotom (rys. 23) miato napęd elektryczny z automatycznym posuwem, jednak w rozwiązaniu tym wprowadzono prowadzenie samoczynne. Serwotom był przeznaczony do cięcia według szablonu przedmiotów o grubości do $200 \mathrm{~mm}$ [25].
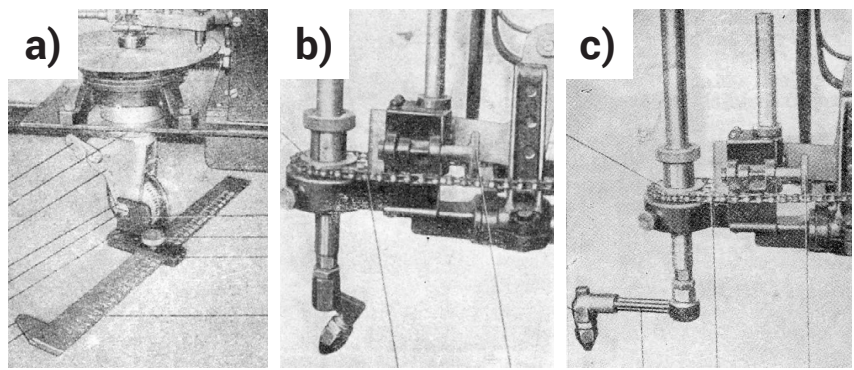

Rys. 21. a) Cyrkiel [27], b) Przyrząd do ukosowania w dowolnym kierunku [27], c) Przyrząd do cięcia kół o dużych średnicach [27]

Fig. 21. a) Compass, b) Device for beveling in free direction, c) Cutting device for wheels of large diameters

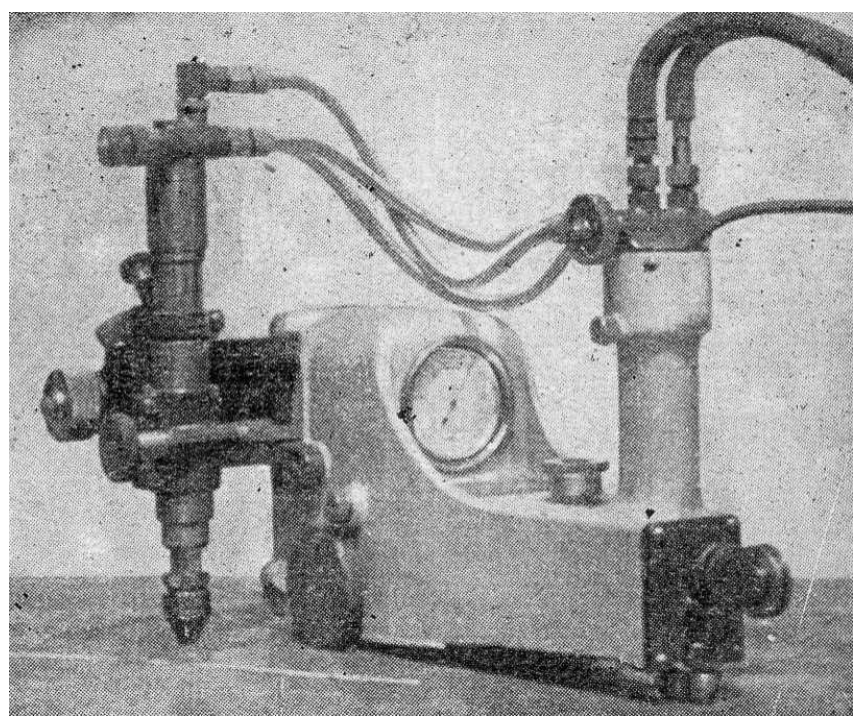

Rys. 22. Maszyna do cięcia Pyrotom [25]

Fig. 22. Pyrotom cutting device

Przy cięciu bloków oraz grubych blach można było stosować proste urządzenie (rys. 24) w kształcie ramy prostokątnej, którą przymocowywało się do przecinanego elementu za pomocą zacisków. W ramie osadzona była śruba pociągowa, obracana korbą, na której przesuwał się uchwyt z zamocowanym palnikiem. Uchwyt był tak skonstruowany, że umożliwiał przechylanie palnika bez przerywania ruchu posuwistego [28].

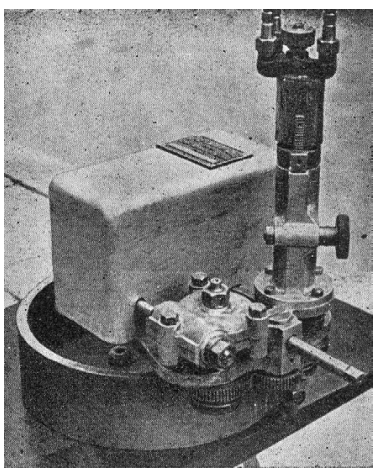

Inne urządzenie do cięcia blo- Fig. 23. Serwotom cutting ków (rys. 25) było wyposażone device

w cztery wysuwane nóżki, dzięki czemu można było ustawić je nad ciętym blokiem, nawet na nierównej podłodze. Maszyna składała się z ramy, do której przymocowane były dwie rury, po których przesuwał się suport. Posuw podłużny suportu uzyskiwano dzięki śrubie pociągowej, na której była umocowana korba ręczna. Do suportu, za pomocą czopa, był przymocowany uchwyt, w którym przesuwała się rura z zamontowanym palnikiem. Takie rozwiązanie umożliwiało regulację odległości palnika od ciętej powierzchni, a także pochylanie palnika w jednym lub drugim kierunku [15]. 


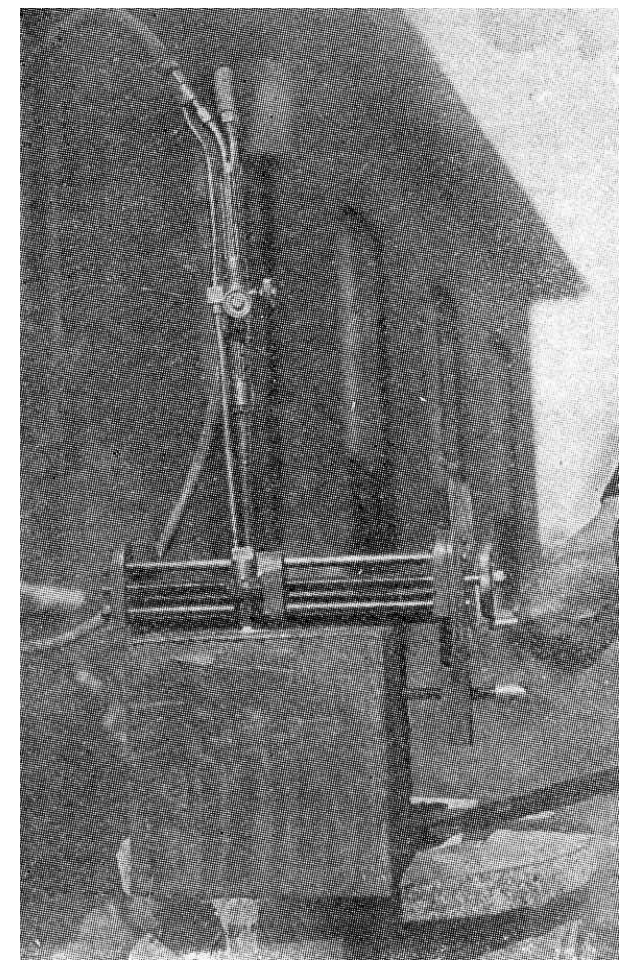

Rys. 24. Maszyna do cięcia półautomatycznego bloków [28] Fig. 24. Device for half-automatic cutting of blocks

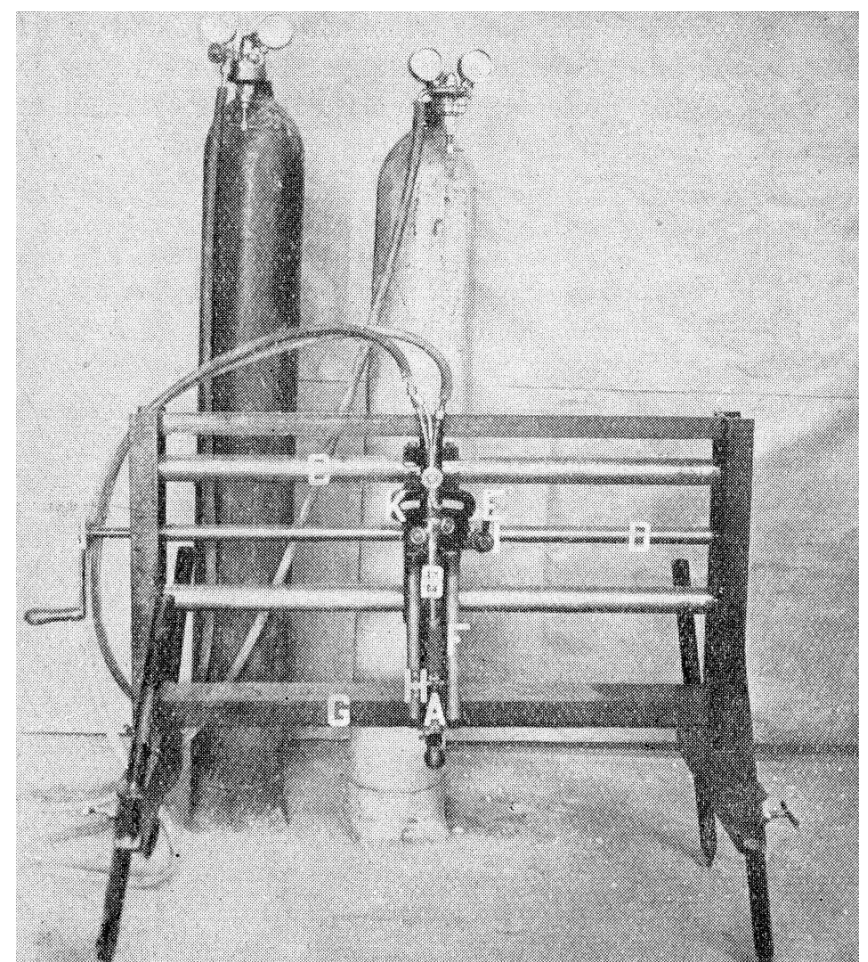

Rys. 25. Maszyna do cięcia bloków [15]

Fig. 25. Device for cutting of blocks

\section{Literatura}

[1] Some historical notes on thermal cutting processes. Welding In the World V.18 No1-2/1980, s.23-35.

[2] S.Anczyc: Nowsze sposoby łączenia blach. Przegląd Techniczny T. XLVIII, nr 20/1910, s.251-253.

[3] Krótka historia spawalnictwa. http://spawalnicy.pl/edukacja/55-krotka-historia-spawalnictwa

[4] J. Zaykowski: Acetylen rozpuszczony. Przegląd Techniczny nr 14/1914, s.183-185

[5] A. Sznerr. Spawanie. Spawanie i Cięcie Metali nr 2/1928, s.12-16.

[6] A. Sznerr. Spawanie. Spawanie i Cięcie Metali nr 3/1928, s.8-12.

[7] A. Sznerr. Spawanie. Spawanie i Cięcie Metali nr 7/1928, s.10-15

[8] Wspomnienie pośmiertne Karl von Linde. Spawanie i Cięcie Metali nr 2/1935, s.33.

[9] E. Almqvist: History of Industrial Gasses. Kluwer Academy Plenum Publishers, New York 2003, s.355-370.

[10] V. Poniż: Cięcie metali. Życie Techniczne Rok X nr 8/1934, s.21-22.

[11] A. Sznerr. Spawanie. Spawanie i Cięcie Metali nr 9/1929, s.149-153.

[12] J. Kwiatkowski: Przecinanie metali za pomocą tlenu. Mechanik $\mathrm{nr} 1 / 1914, \mathrm{~s} .10-12$

[13] Spawanie i cięcie metali. Przegląd Techniczny nr 33-34/1926, s.463-464.

[14] S. Anczyc: Nowsze sposoby łączenia blach. Przegląd Techniczny nr 22/1910, s. 164-184 i 281-283.

[15] Kalendarz Spawalniczy na rok 1936. Sp. Akc. Perun, 1936, s. 165-184 i 322
[16] Cięcie pod wodą przy zastosowaniu tlenu. Spawanie i Cięcie Metali nr 3/1934, s.40-44.

[17] Aparat do udoskonalonego cięcia palnikiem ręcznym. Spawanie i Cięcie Metali nr 10/1928, s.10.

[18] W jaki sposób można samemu zrobić maszynkę do cięcia. Spawanie i Cięcie Metali nr 6/1934, s.112-113.

[19] Jak uprościć cięcie palnikiem. Spawanie i Cięcie Metali nr 8/1929, s.137-138.

[20] Zalety maszynowego cięcia tlenem. Spawanie i Cięcie Metali nr 5/1928, s.16-19.

[21] Skr. Oxygraph przyrząd do cięcia stali. Mechanik nr XIV/1912, s.10-11.

[22] Maszyna Godfrey`a do cięcia metali płomieniem tleno-acetylenowym. Spawanie i Cięcie Metali nr 8/1928, s.19-20.

[23] Nowa maszyna do automatycznego cięcia tlenem. Spawanie i Cięcie Metali nr 3/1929, s.43-44.

[24] Nowe maszyny do cięcia tlenem. Spawanie i Cięcie Metali nr 9/1935, s.147-156.

[25] Kalendarz Spawalniczy nr 7. 1938/1939, s.382-385.

[26] Znaczenie cięcia tlenem w rozwoju spawania. Spawanie i Cięcie Metali $\mathrm{nr}$ 10/1931, s.161-163.

[27] Kalendarz Spawalniczy nr 4/ 1934, s.208-235.

[28] Kalendarz Spawalniczy nr 5/1935, s. 155-158. 